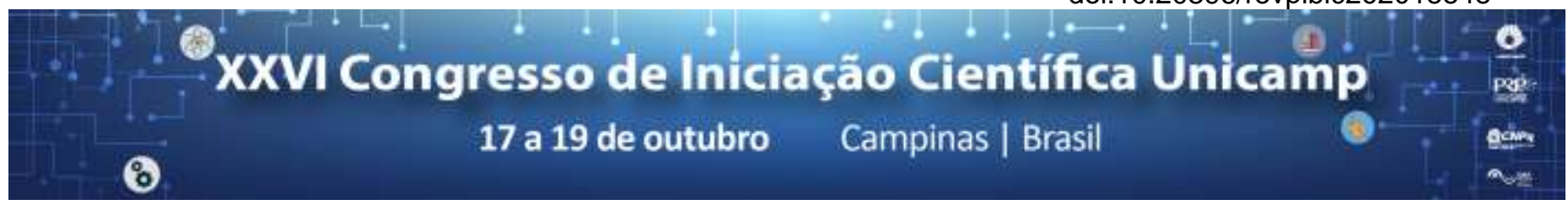

\title{
Gênero e religião na experiência da doença de Alzheimer
}

\author{
Letícia Vicentin*, Guita Grin Debert, Daniela Moreno Feriani
}

\begin{abstract}
Resumo
Além dos aspectos biológicos, outras dimensões também atravessam a experiência da doença, entre elas, o gênero e a religião. Na Residência Carmen Sallés, a doença de Alzheimer é multifacetada e heterogênea, assim como a própria experiência das Irmãs. Reconhecendo a importância dos estudos antropológicos que busquem trazer as percepções dos doentes à tona, a pesquisa caminhou através de uma etnografia de vivência intensa entre as Irmãs e leitura bibliográfica, a fim de acessar os modos pelos quais essas mulheres religiosas vivem e interpretam a doença de Alzheimer. Dentre os dados etnográficos, pode-se compreender que a espiritualidade parece dissolver 0 terror e 0 assombro das confusões e delírios, trazendo possibilidades novas de interpretação.
\end{abstract}

\section{Palavras-chave:}

Antropologia, Doença de Alzheimer, Irmãs.

\section{Introdução}

Ao compreender a Doença de Alzheimer (DA) não apenas como entidade biológica, Feriani (2017) apresenta como ela é atravessada por elementos simbólicos, sociais, biográficos, históricos e que, assim, as Ciências Sociais têm muito com o que contribuir para o tema. As diferentes maneiras de perceber e viver com a doença mostram como os aspectos biológicos, mesmo que importantes, são insuficientes para lidar com a DA.

A Residência Carmen Sallés pertence à Congregação Concepcionista Missionária do Ensino e foi criada para receber as Irmãs que, por motivos de saúde, não podem mais continuar com certos trabalhos da vida religiosa. Formam um grupo de 13 Irmãs e, entre elas, $6 \mathrm{com}$ a DA. Os elementos de gênero e religião, importantes para compreender suas trajetórias de vida, mostraram especificidades também em suas experiências com a doença.

\section{Resultados e Discussão}

A etnografia realizada durante 22 dias em que vivi entre as Irmãs foi tecida de observações cotidianas, entrevistas de história de vida, oficinas de pintura com a composição de desenhos e cartas, e fotografias que registrei. No contexto estudado, há a compreensão de que a DA não afeta a alma, embora afete o corpo, e que, ao mesmo tempo em que existe uma rotina regrada pelo gênero e pela região, existe uma maleabilidade para acolher os sintomas da doença. Por exemplo, uma Irmã dizia sentir saudades de seus pais que moram na Espanha. De acordo com as outras Irmãs, eles não podem estar vivos, dados os 86 anos da Irmã, no entanto, não dizem que estão mortos. "Se estiver morto, está vivo em Deus!", disse uma Irmã quando soube da morte de um irmão vivo de outra. Isso porque, pela lógica religiosa, os pais continuam vivos em espiritualidade. Percebe-se como um possível sintoma de demência acreditar que os pais estão vivos, tido, pelo discurso médico, como uma alucinação - ganha novos sentidos através da religião. Em Vianna (2013), o autor se depara com as disputas de saberes que compreendem os sujeitos com DA como seres híbridos que percorrem as fronteiras entre natureza e cultura, oscilam entre o real e virtual, entre lucidez e delírios. São presentes em nossa sociedade concepções de que o doente que se "dissolve" é "fragmentado", torna-se uma pessoa desconhecida, diante da "perda de si mesma". No entanto, a pesquisa entre as Irmãs mostrou que, para elas, não funciona dessa maneira, uma vez que a religião traz concepções específicas sobre vida, corpo, alma e doença. A vida espiritual prevalece sobre a corporal e, por isso, a DA perde a conotação de algo tão temido, terrível, sofrido.

As imagens fotografadas e desenhadas, importantes metodologicamente, considerando suas potencialidades para o fazer antropológico, oferecem outras linguagens de anunciação, outros modos de ver e conhecer. As composições imagéticas dos resultados da etnografia poderão ser vistas no relatório final da pesquisa, em um artigo posterior e no pôster a ser apresentado no XXVI Congresso de Iniciação Científica Unicamp.

\section{Conclusões}

Através da pergunta de partida - "existem especificidades, considerando gênero e religião, na experiência da doença de Alzheimer pelas Irmãs da Residência Carmen Sallés?" - e os caminhos da pesquisa, pode-se acessar respostas que criaram outras perguntas para uma continuação deste trabalho. Este percurso etnográfico se deparou com outros mundos, possibilidades e experiências, para além do discurso biomédico de fragmentação e dissolução. A pesquisa também buscou se tornar uma contribuição para com os estudos antropológicos das experiências de sujeitos com a enfermidade a partir do ponto de vista deles e com a relação, ainda pouco explorada, entre gênero, religião e doença.

\section{Agradecimentos}

Este trabalho não seria possível sem a orientação cuidadosa da professora Guita Debert e da pósdoutoranda Daniela Feriani. Agradeço também às Irmãs por me receberem brevemente em suas vidas e por todo o aprendizado tecido entre nós. Por fim, agradeço a oportunidade da bolsa de pesquisa SAE/Unicamp.

\footnotetext{
${ }^{1}$ Feriani, D. M. Entre sopros e assombros: estética e experiência na doença de Alzheimer. Tese de doutorado em Antropologia Social. Universidade Estadual de Campinas. Campinas, 2017.

${ }^{2}$ Vianna, L. V. D. G.. Fragmentos de pessoa e a vida em demência: etnografia dos processos demências em torno da doença de Alzheimer. Dissertação de mestrado em Antropologia Social. Universidade Federal do Rio Grande do Sul. Porto Alegre, 2013.
} 